\title{
LIMFOSIT PLASMA BIRU DAN JUMLAH LEUKOSIT PADA PASIEN ANAK INFEKSI VIRUS DENGUE DI MANADO
}

\author{
${ }^{1}$ Rosnatalia D. Arruan \\ ${ }^{2}$ Glady Rambert \\ ${ }^{2}$ Firginia Manoppo
}

\author{
${ }^{1}$ Kandidat Skripsi Fakultas Kedokteran Universitas Sam Ratulangi Manado \\ ${ }^{2}$ Bagian Patologi Klinik Fakultas Kedokteran Universitas Sam Ratulangi Manado \\ Email: rdatuarruan11_087@ymail.com
}

\begin{abstract}
Dengue is an arboviral disease that is widely spread across the world by Aedes mosquitoes. The early onset of dengue virus infection is difficult to identify due to indistinctive clinical symptoms. Therefore, simple laboratory test is required in the early diagnosis of dengue virus infection. Laboratory test that include routine blood test and blue plasma lymphocyte are important as rapid and relatively cheap diagnostic tool. Blue plasma lymphocytes derived from lymphoid which acts as an immune response that can be found in $4 \%$ of peripheral blood on $98 \%$ dengue hemorrhagic fever cases. Besides the increases in blue plasma lymphocytes, dengue virus infection can also causes leucopenia. Leucopenia in Dengue Hemorrhagic Fever (DHF) is characterized by the decrease of neutrophile count that happened during the early critical phase (third day of fever). This is a cross-sectional study using samples of 37 children who are infected with dengue virus in RS Advent Manado, RS TNI AD Wolter Monginsidi, RS Pancaran Kasih Manado during December 2014 to January 2015. Inclusion criteria are children below age 15, who have NS1 or IgG/IgM positive, who are on the third until seventh day of fever, whose parents or guardian have signed the informed consent. Conclusion: Leucopenia (leukocyte count below $4000 / \mathrm{mm}^{3}$ ) was found in children with dengue virus infection who had their routine blood test. Blue plasma lymphocytes are not always found in patients with NS1-AG, IgG/IgM positive.
\end{abstract}

Keywords: dengue virus infection, leucocyte, blue plasma lymphocyte

\begin{abstract}
Abstrak: Dengue adalah penyakit arboviral yang paling banyak tersebar di dunia yang ditularkan nyamuk Aedes. Awal infeksi virus dengue sulit untuk dikenali sebab tidak menunjukkan gejala klinis khas. Karena itu, pemeriksaan laboratorium sederhana dapat berperan dalam pengenalan infeksi virus, adalah pemeriksaan darah rutin dan limfosit plasma biru yang cepat dan murah. Limfosit plasma biru sebagai respon imun dengan persentase $4 \%$ di darah tepi pada $98 \%$ kasus demam beradarah dengue. Selain peningkatan limfosit plasma biru, infeksi virus dengue juga dapat menyebabkan leukopenia. Leukopenia pada demam berdarah dengue didominasi penurunan jumlah neutrofil yang terjadi pada awal fase kritis (hari ketiga demam). Penelitian ini menggunakan desain cross sectional dengan sampel penelitian 37 pasien anak yang terinfeksi virus dengue di RS Advent Manado, RS TNI AD Wolter Mongisidi, RS Pancaran Kasih Manado pada bulan Desember 2014 sampai Januari 2015. Kriteria masukan adalah Anak usia kurang dari 15 tahun, hari ketiga sampai ketujuh demam, NS1 atau IgG/IgM positif, Orangtua atau wali bersedia menandatangani informed consent. Simpulan: Pada pasien anak dengan infeksi virus dengue yang dilakukan pemeriksaan darah rutin ditemukan adanya leukopenia dengan jumlah leukosit dibawah $4000 / \mathrm{mm}^{3}$.
\end{abstract}

Kata kunci: infeksi virus dengue, leukosit, limfosit plasma biru 
Dengue adalah penyakit arboviral yang paling banyak tersebar di dunia, yang ditularkan melalui nyamuk Aedes aegypti dan Aedes albopyctus. ${ }^{1,2}$ Virus dengue terdiri atas RNA rantai tunggal yang mempunyai empat serotipe yang dikenal dengan DEN-1, DEN-2, DEN-3, dan DEN4. Infeksi dari salah satu serotipe virus menimbulkan gejalah seperti flu yang disebut demam dengue (DD), dengan gejala klinis yang berat disebut demam berdarah dengue (DBD). ${ }^{1}$

Dua per lima dari penduduk dunia yang tinggal di daerah tropis dan sub tropis berisiko terinfeksi virus dengue. ${ }^{1}$ Diperkirakan 500.000 orang memerlukan rawat inap setiap tahun dan proporsinya 90\% dari mereka anak yang berusia dibawah lima belas tahun. ${ }^{1-3}$

Pada tahun 2012, kasus demam berdarah dengue di Indonesia dilaporkan sebanyak 90.245 orang dengan angka kematian 816 orang. ${ }^{4}$ Kasus demam berdarah dengue di propinsi Sulawesi utara selama tahun 2013 berjumlah 1.149 kasus, dan kota Manado menempati posisi tertinggi dengan jumlah 410 kasus dengan insiden rate (IR) 100,40 dan case fertility rate (CFR) 0,98 \%. Dibandingkan data tahun 2014 bulan Januari sampai bulan Agustus kota Manado tetap menempati posisi tertinggi dengan jumlah 255 kasus, insiden rate 62,45 dan case fertility rate 3,29 \%. Data ini terlihat bahwa tahun 2014 dengan insiden rendah namun case fertility rate lebih tinggi dibanding tahun 2013. (Dinas kesehatan provinsi Sulawesi utara, 2013-2014). ${ }^{5}$

Awal infeksi virus dengue sulit untuk dikenali sebab tidak menunjukkan gejala klinis yang khas, oleh karena itu diperlukan pemeriksaan laboratorium sederhana yang dapat berperan dalam pengenalan infeksi virus dengue. Pemeriksaan laboratorium tersebut ialah pemeriksaan limfosit plasma biru yang bermanfaat dalam diagnostik dengue dengan cepat dan murah. Limfosit plasma biru adalah limfosit reaktif dari limfoid sebagai respon imun dengan persentase 4\% di darah tepi yang terdapat pada 98\% kasus demam beradarah dengue, peningkatan ini ditemukan pada hari ketiga sampai hari ketuju demam. ${ }^{6}$

Selain peningkatan limfosit plasma biru, infeksi virus dengue dapat menyebabkan leukopenia tetapi keadaan ini sering diabaikan pada penatalaksanaan demam berdarah dengue. ${ }^{7}$ Leukopenia pada demam berdarah dengue didominansi penurunan jumlah neutrofil yang terjadi pada awal fase kritis (hari ketiga demam). ${ }^{8,9}$

Berdasarkan uraian latar belakang diatas maka penulis tertarik untuk meneliti limfosit plasma biru dan jumlah leukosit pada pasien anak infeksi virus dengue di Manado.

\section{METODE PENELITIAN}

Penelitian ini menggunakan desain cross sectional, sampel penelitian 37 pasien anak yang terinfeksi virus dengue pada bulan Desember 2014 sampai Januari 2015 di RS. Advent manado, RS TNI AD Wolter Monginsidi, RS Pancaran Kasih Manado.

Subjek penelitian ialah pasien terinfeksi virus dengue sesuai kriteria masukan, NS1 dan atau IgG/IgM positif, anak usia $<15$ tahun, hari ketiga sampai ketujuh demam, serta orangtua/wali bersedia menandatangani informed consent.

Data hasil pemeriksaan kemudian diolah menggunakan program SPSS 20 for windows dan disajikan dalam bentuk tabel.

\section{HASIL PENELITIAN}

Terdapat 37 sampel penelitian yang memenuhi kriteria inklusi pada bulan desember 2014 sampai januari 2015.

Tabel 1. Distribusi pasien infeksi virus dengue berdasarkan usia

\begin{tabular}{ccc}
\hline $\begin{array}{c}\text { Kelompok } \\
\text { usia }\end{array}$ & $\begin{array}{c}\text { Frekuensi } \\
\text { (orang) }\end{array}$ & $\%$ \\
\hline$<1$ Tahun & 1 & 2,7 \\
1-4 Tahun & 6 & 16,2 \\
5-14 Tahun & 30 & 81,1 \\
\hline Total & 37 & 100 \\
\hline
\end{tabular}


Tabel 2. Distribusi pasien infeksi virus dengue berdasarkan lama demam

\begin{tabular}{ccc}
\hline $\begin{array}{c}\text { Lama Demam } \\
\text { (hari) }\end{array}$ & $\begin{array}{c}\text { Frekuensi } \\
\text { (orang) }\end{array}$ & $\%$ \\
\hline Hari ke 3 & 21 & 56,8 \\
Hari ke 4 & 9 & 24,3 \\
Hari ke 5 & 7 & 18,9 \\
\hline Total & 37 & 100 \\
\hline
\end{tabular}

Tabel 3. Hasil pemeriksaan NS1 dengue, IgG/IgM anti dengue

\begin{tabular}{ccc}
\hline Pemeriksaan & Frekuensi & $\%$ \\
\hline NS1 & 22 & 59,5 \\
IgG + IgM - & 14 & 37,8 \\
IgG - IgM + & 1 & 2,7 \\
\hline Total & 37 & 100 \\
\hline
\end{tabular}

Tabel 4. Interpretasi jumlah leukosit

\begin{tabular}{ccc}
\hline Interpretasi leukosit & $\begin{array}{c}\text { Jumlah } \\
\text { (orang) }\end{array}$ & $\%$ \\
\hline $\begin{array}{c}\text { Leukopenia } \\
\left(<4000 / \mathrm{mm}^{3}\right)\end{array}$ & 24 & 64,9 \\
$\begin{array}{c}\text { Normal } \\
\left(4000-10000 / \mathrm{mm}^{3}\right)\end{array}$ & 13 & 15,1 \\
$\begin{array}{c}\text { Leukositosis } \\
\left(>10000 / \mathrm{mm}^{3}\right)\end{array}$ & 0 & 0 \\
\hline Total & 37 & 100 \\
\hline
\end{tabular}

Tabel 5. Nilai leukosit

\begin{tabular}{llllc}
\hline $\begin{array}{l}\text { Jumlah } \\
\text { sampel }\end{array}$ & $\begin{array}{l}\text { Rerata } \\
(\mathrm{mm} 3)\end{array}$ & $\begin{array}{l}\text { Nilai } \\
\text { tertinggi } \\
(\mathrm{mm} 3)\end{array}$ & $\begin{array}{l}\text { Nilai } \\
\text { terendah } \\
(\mathrm{mm} 3)\end{array}$ & $\begin{array}{c}\text { Simpang } \\
\text { baku } \\
(\mathrm{mm} 3)\end{array}$ \\
\hline 37 & 3600 & 9700 & 700 & 1965,520 \\
\hline
\end{tabular}

Tabel 6. Jumlah limfosit plasma biru (LPB)

\begin{tabular}{ccc}
\hline Interpretasi LPB & Frekuensi & $\%$ \\
\hline Positif & 13 & 35,1 \\
Negatif & 24 & 64,9 \\
\hline Total & 37 & 100 \\
\hline
\end{tabular}

\section{BAHASAN}

Hasil uji NS1 maupun serologi IgG/IgM menunjukkan bahwa frekuensi tertinggi ialah NS1 positif dengan jumlah 22 orang (59,9\%), kemudian IgG dengan jumlah 14 orang $(37,8 \%)$ dan yang terendah IgM yaitu satu orang (2,7\%).
Berdasarkan hasil penelitian ini diperoleh 24 orang dari 37 pasien memenuhi kriteria masukan dan tolakan yang mengalami leukopenia dengan jumlah leukosit dibawa $4000 / \mathrm{mm}^{3}$, dengan nilai terendah $700 / \mathrm{mm}^{3}$, tertinggi $9700 \mathrm{~mm}^{3}$ dan nilai rata-rata $3600 / \mathrm{mm}^{3}$. Hal ini, didukung oleh hasil penelitian Risniati, $\mathrm{dkk}^{7}$ yang dilakukan pada 129 sampel penelitian yang memenuhi kriteria inklusi seluruhnya mengalami leukopenia dengan jumlah dibawah $5000 / \mathrm{mm}^{3}$.Sesuai dengan hasil penelitian yang diperoleh maka pasien yang menjadi sampel pada umumnya berada pada awal fase kritis, Sesuai dengan teori yang mengatakan bahwa pada infeksi virus dengue akan ditemukan leukopenia pada awal fase kritis (hari ketiga demam). ${ }^{8}$

Limfosit plasma biru pada penelitian ini ditemukan lebih banyak yang negatif dibandingkan positif, dari total sampel 37 ditemukan 13 orang $(35,1 \%)$ positif dan 24 orang $(64,9 \%)$ negatif. Penelitian ini ditemukan Limfosit plasma biru pada pasien yang diperiksa hari ketiga demam sebanyak lima orang, hari keempat dan kelima demam masing-masing lima orang. Teori mengatakan bahwaLimfosit plasma birumerupakan sel berinti satu (mononuklear) dengan struktur kromatin inti halus dan agak padat, serta sitoplasma yang relatif lebar dan berwarna biru tua, yang ditemukan sejak hari ketiga demam. ${ }^{6}$ Limfosit plasma biru diperiksa dengan teknik pemeriksaan blood smear yang dilakukan secara manual oleh dokter di laboratorium, juga dapat dipengaruhi oleh teknik pembuatan hapusan yang tidak tepat, serta kesalahan dalam menganalisis. Karena itu hasil pemeriksaan limfosit plasma biru ini dapat bersifat subjektif.

Hasil pemeriksaan darah rutin yaitu jumlah leukosit tidak dapat dijadikan parameter tunggal dalam mendiagnosis pasti pasien infeksi virus dengue karena sensitivitasnya rendah, pada penelitian ini jumlah sampel masih kurang serta tidak mengklasifikasikan derajat penyakit sehingga sulit menentukan jumlah rata-rata 
limfosit plasma biru pada masing-masing derajat penyakit. Penelitian Irianti, $\mathrm{dkk}^{10}$ mengelompokkan jumlah limfosit plasama biru berdasarkan spektrum klinis menemukan jumlah rata-rata limfosit plasma biru pada DD adalah $4 \%$, DBD $8,2 \%$, SSD 13,5\% dan juga menemukan bahwa pasien DD dan DBD mengalami puncak pada hari keenam sakit.

Kelebihan penelitian ini adalah dengan memadukan pemeriksaan NS1 dengue atau IgG/IgM anti dengue dengan pemeriksaan darah rutin, maupun pemeriksaan limfosit plasma biru. Membantu dalam mendiagnosis pasien yang dicurigai terinfeksi virus dengue lebih cepat agar dapat dilakukan penanganan secara cepat dan tepat.

\section{SIMPULAN}

Berdasarkan hasil penelitian dan pembahasan yang telah dijabarkan penulis menarik kesimpulan :

1. Terdapat pasien anak dengan infeksi virus dengue yang dilakukan pemeriksaan darah rutin ditemukan leukopenia dengan jumlah leukosit dibawa $4000 / \mathrm{mm}^{3}$.

2. Pasien dengan NS1 dengue, IgG/IgM anti dengue positif tidak semua ditemukan adanya limfosit plasma biru.

\section{DAFTAR PUSTAKA}

1. IBN Dwipayana Manuaba, I Wayan Putu Sutirtayasa , DAP Rasmika Dewi. Immunopatogenesis infeksi virus dengue. Jurnal Patologi Klinik. 2011.

2. Candra A. Demam berdarah dengue: Epidemiologi, Patogenesis, dan faktor risiko penularan. Aspirator. 2010;
2(2) p. 110-19.

3. World Health Organization. Comprehensive guidline for prevention and control of dengue and dengue haemorrhagic fever. SEARO. 2011;60: 2-32.

4. Hadinegoro SR, Moedjito I, Chairulfatah A. Pedoman diagnosis dan tata laksana infeksi virus dengye pada anak. Edisi ke-1. Badan penerbit Ikatan Dokter Anak Indonesia; 2014. p. 1-12, 32-6.

5. UPTD Balai data, survelans dan SIK. Seksi surveilans dan litbangkes. Dinas Kesehatan Provinsi Sulawesi Utara. 2013-2014.

6. Nany. Limfosit plasma biru nilai diagnosis pada infeksi dengue.2007. [Tesis]. [diakses 15 oktober 2014] Diunduh dari : resipitory.usu.ac.id bitsream. USU e-Repository (C) 2008.

7. Risniati Y, Tarigan LH, Tjitra E. Leukopenia sebagai prediktor sindrom syok dengue pada anak dengan demem berdarah dengue di RSUPI. Prof. dr. Sulianti Saroso. 2013;21(3) p.96-103.

8. World Health Organisation. Dengue guidelines for diagnosis, treatment, prevention and control. Perancis. 2009.p. 1-17.

9. Setrkraising K, Bongsebandhuphubhakdi C, Voraphani N, Pancharoen C, Thisyakorn U, Thisyakorn C. D-dimer as an indicator of dengue severity. Asian Biomedicine. 2007;1(1): 54-7.

10.Irianti DM, Reniarti L, Azahli MS. Hubungan jumlah leukosit dan limfosit plasma biru dengan spectrum klinis dan peranannya dalam memprediksi perubahan spectrum klinis infeksi dengue pada anak. Sari Pediatri. 2009;10(5) p. 325-30. 